\begin{tabular}{lllllllllllllllllllllllllllllllll}
\hline$R$ & $E$ & $V$ & I & S & T & A & D & E & E & S & T & U & D & I & O & S & I & N & T & E & R & N & A & C & I & O & N & A & L & E & S
\end{tabular}

\title{
The Globalization of Nationality
}

Exposición del profesor Francisco Orrego Vicuña en la sesión inaugural de la Conferencia sobre "La nacionali-

Documentos dad y las reclamaciones en los tratados sobre inversiones», realizada en el British Institute of International and Comparative Law, Londres, 6 de mayo de 2005.

Among the many startling features of contemporary international society, that concerning nationality in the context of international claims is particularly noticeable. This Conference is a most timely effort at discerning trends and issues that at first sight may appear intriguing, but which are in fact the outcome of the globalization of human endeavours, particularly in the fields of trade and investment.

The essence of the evolution taking place since the 1950's, is that step by step nationality has followed a process of de-linking from the nation State so as to become an element of interconnection with the framework governing the activities concerned. As that framework is now global for the most, so too nationality responds to the rights and obligations of individuals under international law. Contradictory as it may appear, nationality in respect of those activities is no longer exclusively national but also global.

This process began with a rather simple but fundamental question concerning whose rights are asserted in international claims. The Permanent Court of International Justice had well laid down 
the rule characterizing an inter-State system of international law when it held in the Mavrommatis Concessions case that by taking up the case of one of its subjects the State was in reality asserting its own rights. It was the time of classic diplomatic protection and its discretionary espousal of claims and the disposition of compensation by the State.

The inherent legal contradictions embodied in this approach and the political use of diplomatic protection as an instrument of power politics had been noted since the very outset, as we have recently been reminded by the work of the International Law Commission and the International Law Association on this matter. The Calvo Clause, aiming at eliminating the role of diplomatic protection and replacing it by the resort to domestic courts, was a first major reaction against this situation.

There was, however, a different kind of reaction in line with the requirements of the international legal system. This was the view that in protecting their nationals States were not asserting their own rights but those of the injured individual. This new approach would have major consequences. First, protection began to lose its diplomatic or political character, as the State was no longer the claimant but rather the conduit for bringing an international claim. Next, why could the individual not have direct standing on his own for bringing claims under international law?

This premise brought about one of the biggest changes in international law ever: the gradual reshaping of the whole system of international dispute settlement and the direct access of individuals to such system. Human rights and foreign investments are but two examples of a change that is likely to continue. More and more disputes will be handled outside the system of diplomatic protection, which has in fact become the residual mechanism for international claims. It is not a question that the State is fading away, as it is the major actor of the international legal system, but rather that it is opening up to, and beginning to operate in the context of global society and thus facilitating the role of individuals therein.

A major consequence of this change in the law is that now the State has been clearly conceived as an entity at the service of the individual and not the other way around, as it was for far too long. Even in areas where the State keeps discretionary powers as to 
the exercise of diplomatic protection, these powers are not beyond the scrutiny of courts, as recent English cases have made clear.

Changes are also apparent in connection with the requirements of an effective link of nationality. The principle of effectiveness outlined in the Nottebohm case is still a central tenet of the international legal system, but the law concerning international claims has for quite some time introduced an important degree of flexibility when the needs of justice are to be better served. Espousal of non-nationals in certain circumstances, protection of nationals of the defendant State and recognition of the right to claim of stateless persons, are some examples of this major innovation.

Not only the rules on continuance of nationality, transferability of claims and double nationality have become better adapted to the new realities of international law, but also the operation of international financial and insurance markets have gained in effectiveness as a result.

It could come as no surprise that in this context the requirements of nationality concerning corporations would also dramatically change as such legal entities are still more closely related to the internationalization of capital. The dictum of the International Court of Justice in the Barcelona Traction case restricting international claims to the State of incorporation of the affected company, not only did not settle the issue posed but also failed to identify the genuine interest associated to the investment. The Court did not ignore the trends that were already at hand in connection with the ICSID Convention, but decided to privilege the formal bar of nationality over the substance of the underlying economic reality.

It would not take long for the Court to mend its course on the matter, as was well evidenced by its decision in the Elsi case, where shareholders of a foreign company were protected by their State of nationality against the State of incorporation. A massive State practice followed, first by gradually lowering the percentage of the interest in a foreign company that was required to bring a claim, ranging from the $100 \%$ interest present in Elsi to a $50 \%$ in various bilateral treaties, and thereafter to a $25 \%$, or even a $4 \%$.

Next, and most significant in this respect, have been the rules governing claims in the United Nations Claims Commission. Di- 
rect submission of claims by affected companies even in the absence of espousal by the State of incorporation, submission of claims by one State on behalf of companies or nationals of another State, claims by shareholders otherwise barred because of nationality and proportional partnership claims, are some of the novel features of this system. It must also be noted that under Resolution 123 (2001) an elaborate claims system was established when the real owner could not appear as shareholder because of domestic legal restrictions.

The evolution noted is at the very heart of the series of ICSID, UNCITRAL and NAFTA cases that for the past fifteen years have opted for looking beyond the formal legal personality of both States and corporations, searching to identify the real economic interest protected under the applicable rules of international law. Bilateral investment treaties, free trade agreements and contracts have of course been the source of such applicable rules.

In Goetz v. Burundi, the Tribunal summarized this view when holding that the right of action in ICSID case law was not restricted "aux seules persones morales directemente visèes par les mesures litigieuses mais l'ètend aux actionnaires de ces personnes, qui sont les veritables investisseurs".

The right of action of locally incorporated companies having the nationality of the very State they are taking to court insofar an international claim is concerned, has also been recognized by the ICSID Convention when the distinguishing feature of foreign control intervenes and so is agreed by the respective States. The reason is again the same, because otherwise the formal issue of nationality would prevent a claim by whom believes to have made the real economic loss.

Investment treaties have on occasion gone beyond this alternative and have allowed for claims of minority or indirect shareholders that are not in control of the corporation concerned. Quite rightly, the argument has been made that this approach could lead to an endless chain of claims which would allow for the right of action of a company that has invested in a company that in turn has invested in another company and thereon.

Yet again here the answer seems to be, as held in a number of recent cases, not to bar claims by individual shareholders separate from the company on that fact alone, but to require that it be shown 
that the treaty in question has extended protection to shareholders and the consent to arbitration has been given by the State in connection to such investors. Not dissimilar approaches have also been recently followed by domestic courts and legislation.

True as it is that such applicable rules are found in treaties and not in customary international law, the real issue lies not in a jurisprudential debate about treaties and custom but in a rather factual assessment. Most investment disputes are today settled under the rules of treaties made specifically to this effect, and only marginally under customary rules governing international claims. The lex specialis has thus become the lex generalis. Irrespectively of issues of hierarchy among rules of international law, this evolution cannot be held to be without effect on general international law.

Historically, States had built a formidable barrier against claims by investors, not on rules concerning substantive rights, that had been accepted under both customary and treaty law, but on rules concerning jurisdiction. If a company lacked the nationality of the claiming State, if a company was not allowed to claim in its own right and if shareholders could not claim independently of the locally incorporated company, there was simply no way to make effective the eventual State responsibility for actions contrary to the applicable rules of international law.

This has also changed in respect of investments, just as it had changed earlier in respect of human rights and will continue to change in respect of other matters, most probably international trade. If States have agreed to standards of substantial treatment and protection of individuals, the issue is then that the parties be allowed to take their case and arguments before an independent tribunal that will decide who is right or wrong.

Nationality will always be a legitimate expression of allegiance to the nation-State, but in the framework of a global community it must not stand as a bar to the exercise of justice. On the contrary, rights and obligations are to be judged in the precise context to which they relate and in which they arise. Change in the pursuance of justice must always be welcome. 